

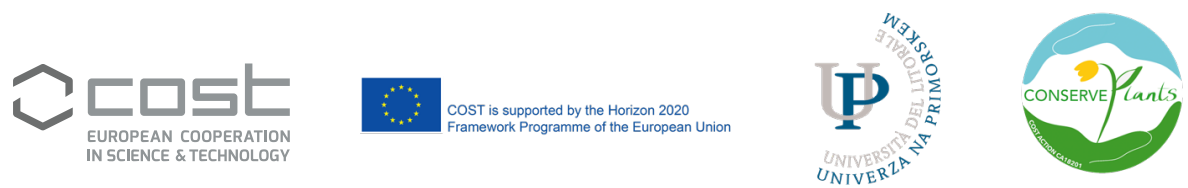

\section{CITES Plants of Europe}

Editors: Živa Fišer and Alicja Kolasińska

Authors of text: Dalibor Ballian, Anna Cwener, Panayiotis Dimitrakopoulos, Živa Fišer, Katerina Goula, Michael Kiehn, Alicja Kolasińska, Theodora Petanidou, Martin Rose, and Elżbieta Skrzymowska

Author of illustration: Alicja Kolasińska

Authors of photographs: Faruk Bogunić, Anna Cwener, Peter Glasnović, Katerina Goula, Alicja Kolasińska, Vitomil Kržišnik, Elżbieta Skrzymowska, Jošt Stergaršek, and Krzysztof Wojciechowski

Peer review: Jasmin Joshi and Peter Glasnović

Language editor: Amy Simmons

Design: Jan Grbac, Alicja Kolasińska \& Tina Vraneš

Published by University of Primorska Press, Titov trg 4, 6000 Koper

www.hippocampus.si

Koper | 2021

Electronic edition | Distributed free of charge

(C) 2021 University of Primorska

https://www.hippocampus.si/ISBN/978-961-293-106-3.pdf

https://www.hippocampus.si/ISBN/978-961-293-107-0/index.html

https://doi.org/10.26493/978-961-293-106-3

Kataložni zapis o publikaciji (CIP) pripravili

v Narodni in univerzitetni knjižnici v Ljubljani

COBISS.SI-ID 78186755

ISBN 978-961-293-106-3 (pdf)

ISBN 978-961-293-107-0 (html) 


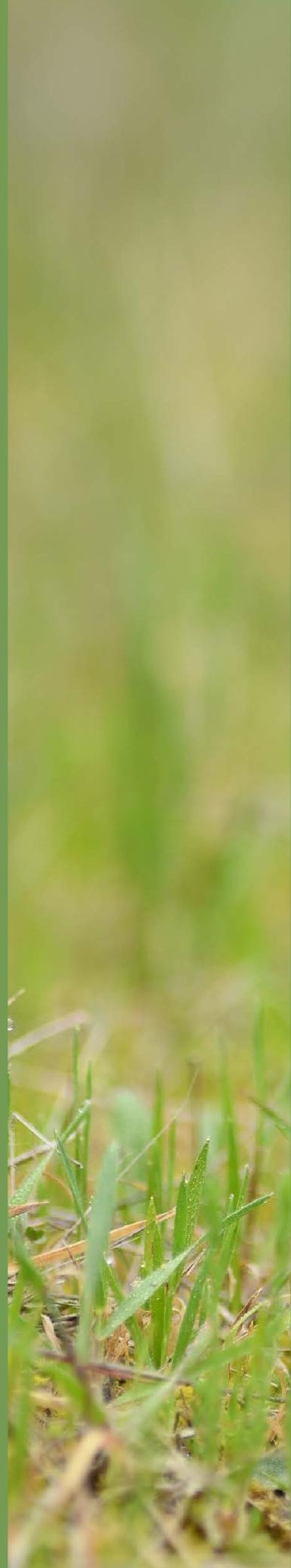




\section{ConservePlants - An integrated approach to conservation of threatened plants for the 21st Century}

Even though plants represent an essential part of our lives offering exploitational, supporting and cultural services, we know very little about the biology of the rarest and most threatened plant species, and even less about their conservation status. Rapid changes in the environment and climate, today more pronounced than ever, affect their fitness and distribution causing rapid species declines, sometimes even before they had been discovered. Despite the high goals set by conservationists to protect native plants from further degradation and extinction, the initiatives for the conservation of threatened species in Europe are scattered and have not yielded the desired results.

The main aim of this COST Action is to improve plant conservation in Europe through the establishment of a network of scientists and other stakeholders who deal with different aspects of plant conservation, from plant taxonomy, ecology, conservation genetics, conservation physiology and reproductive biology to protected area's managers, not forgetting social scientists, who are crucial when dealing with the general public. 


\title{
The Washington Convention
}

\author{
(CITES)
}

Currently, an increasing decline in global biodiversity is being observed. The main reason is the loss of habitats and modifications of natural systems. The second important factor of species decline is their over-exploitation.

A special agreement on international trade in endangered species of wild animals and plants, called the Washington Convention or CITES (Convention on International Trade in Endangered Species of Wild Fauna and Flora) regulates this practice. The text of the Convention was agreed upon in 1973 at a meeting in Washington, D.C. with the aim to protect certain animal and plant species against over-exploitation through international trade and maintain those species throughout their range at a level consistent with their role in the ecosystem. Currently, 182 countries and the European Union (EU) are Parties to the Convention worldwide.

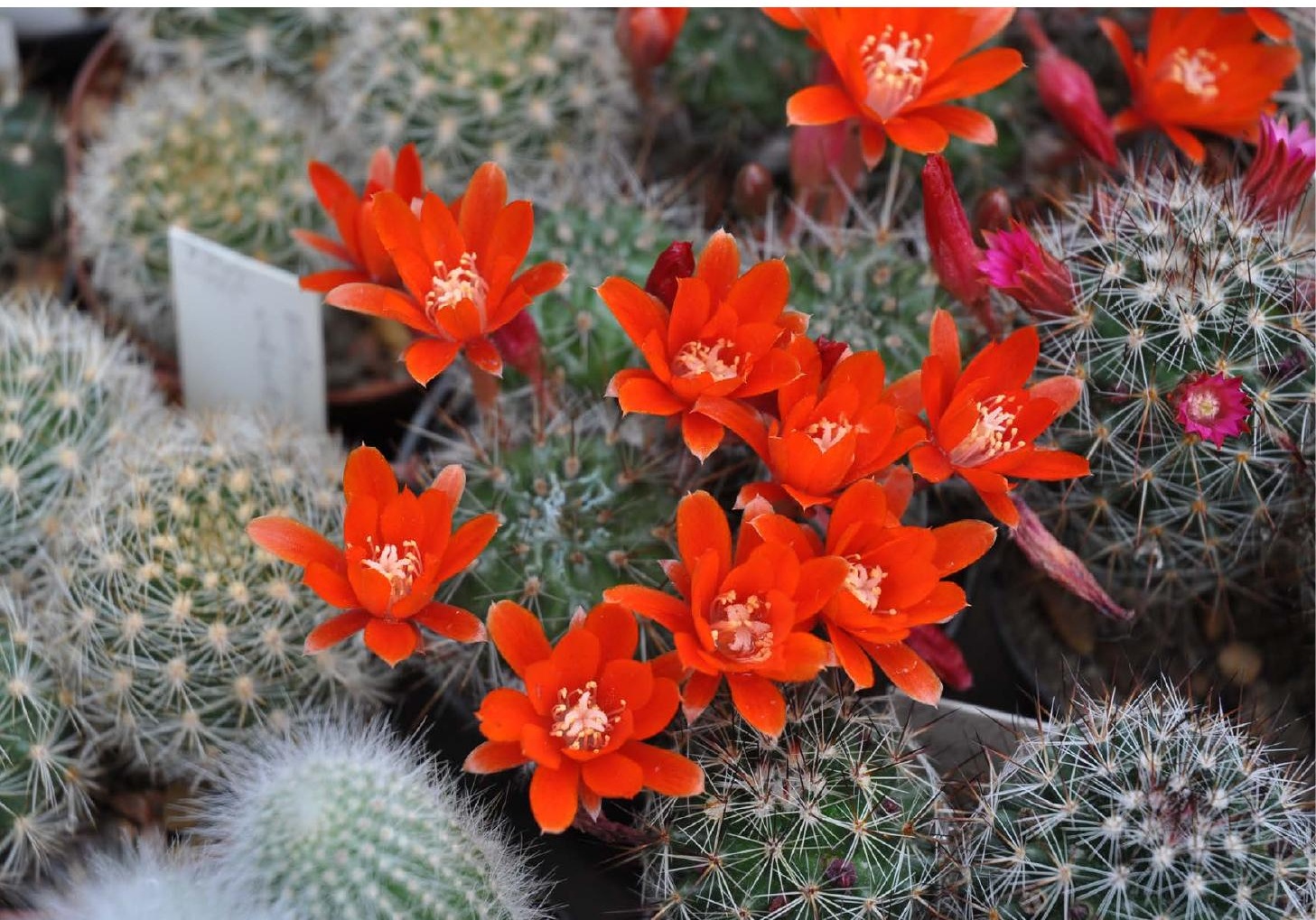


The Convention encompassess three Annexes including approximately 30,000 species of plants and 5,800 species of animals. Their protection is slightly different according to the Annex they are in and is connected with their threat status.

Annex I-includes over 1,000 species threatened with extinction. Trade is only permitted in exceptional cases.

Annex II-there are about 35,000 species that are currently not endangered, but the trade must be controlled, as acquisition of specimens from the wild may lead to their extinction.

Annex III-contains about 220 protected species in at least one country that has asked CITES Parties for help in controlling trade.

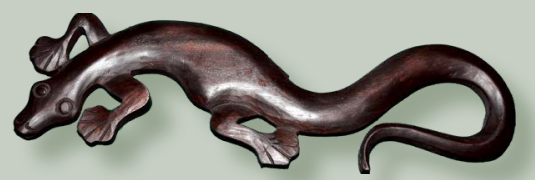

Text: MICHAEL KIEHN, MARTIN ROSE

Photo: ALICJA KOLASIŃSKA 


\section{European Union regulations regarding CITES}

Since 1 June 1997, the trade of CITES specimens with and within the European Union is regulated by Council Regulation No. 338/97 on 9 December 1996 on the protection of species of wild fauna and flora. It translates CITES principles into the realities of the Union, and in many cases significantly tightens them. 


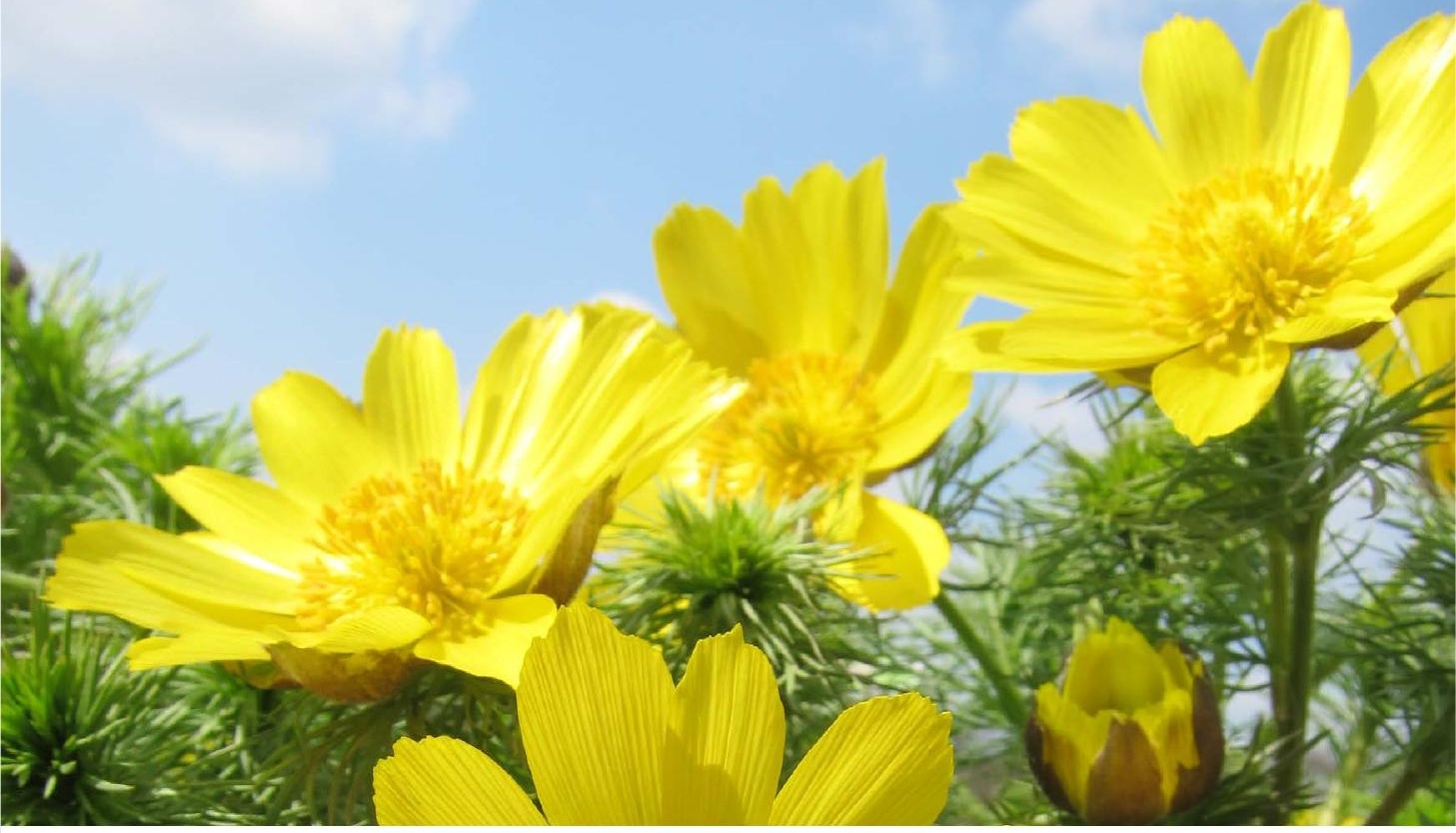

This Regulation contains lists of species subjected to restrictions, listed in four annexes, marked with the letters A, B, C and D. As with CITES attachments, each of these annexes has slightly different restrictions. The Regulation introduces all CITES provisions, but also sets out a number of others. For example, it prohibits commercial exploitation (including sales) in the EU of all species of Annex $A$, and for species of Annex $B$ with no proof of legal origin. The four annexes contain all species listed in Annexes I and II CITES as well as a number of other species protected in the Union.

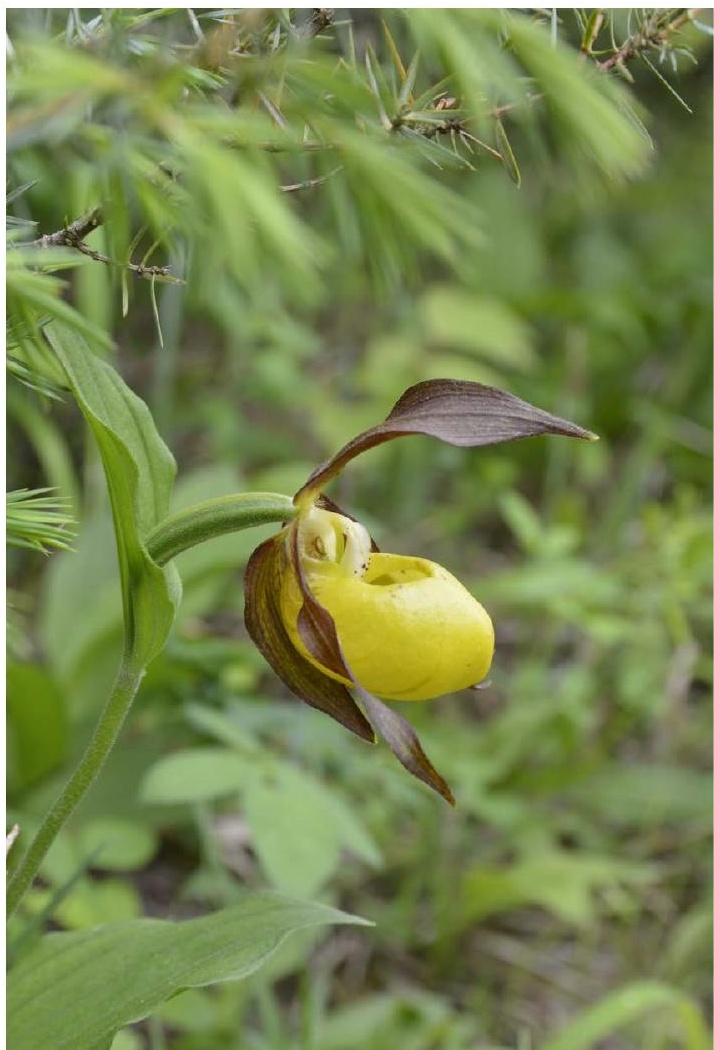




\section{Pheasant's eye}

Adonis vernalis L.

\section{DESCRIPTION}

Perennial plant up to $40 \mathrm{~cm}$ tall with multi-pinnate leaves with large, bright golden, shiny flowers.

\section{HABITAT}

Xerothermic grasslands. Dry, sunny hills, thickets, forest edges, on a limestone or gypsum substrate.

\section{DISTRIBUTION}

Southeastern Europe, to the Urals, with several disjunct populations in southwestern and central Europe.

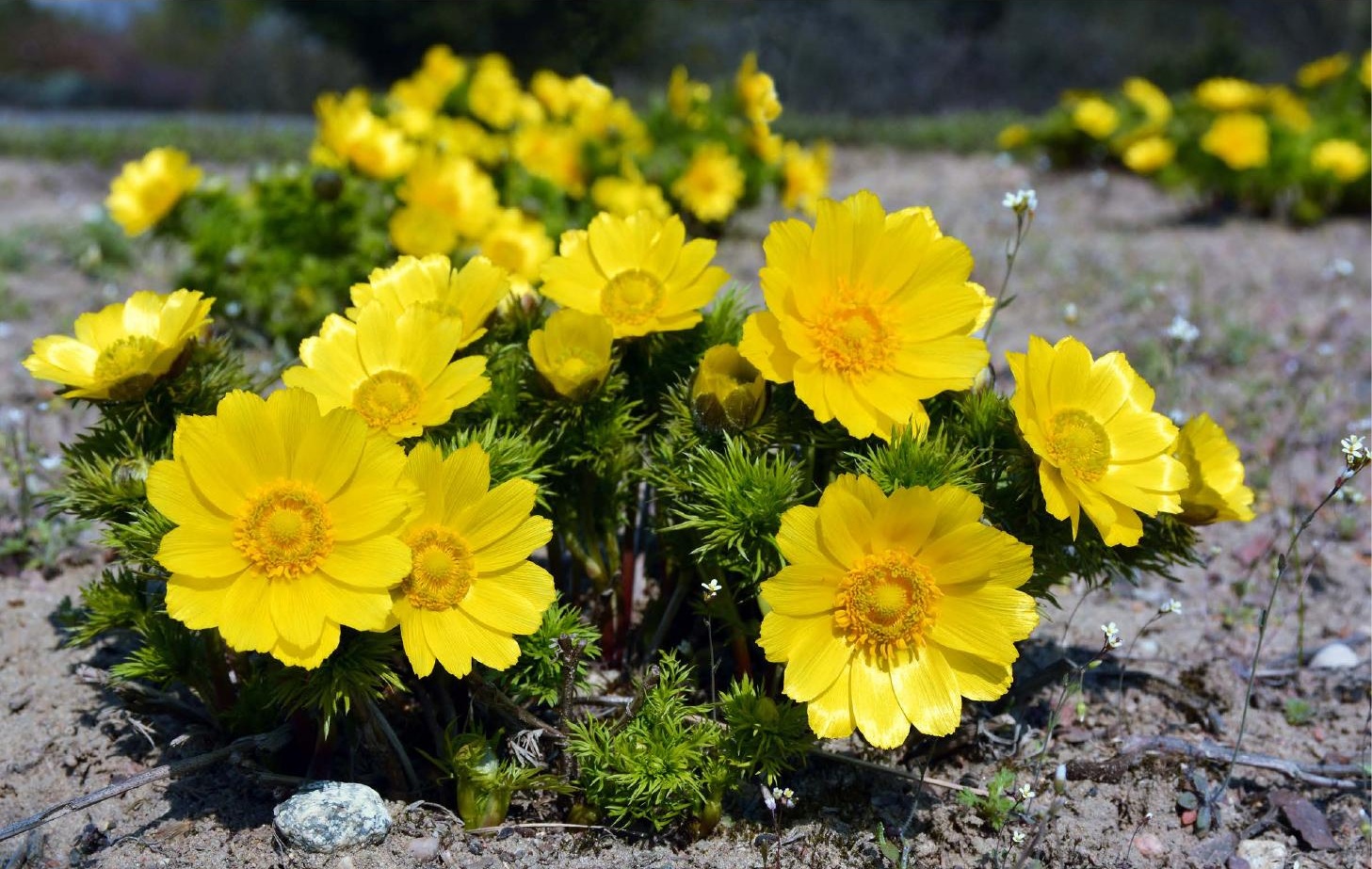





\section{Wavy cyclamen}

Cyclamen repandum Sibth. \& Sm.

\section{DESCRIPTION}

Perennial with a small tuber and heart-shaped leaves. Flowers uniformly bright cerise pink or pale pink with a darker basal zone.

\section{HABITAT}

Coniferous or deciduous woodland and scrub, in moist, shady places.

\section{DISTRIBUTION}

Southern Europe, from France to the Aegean region.

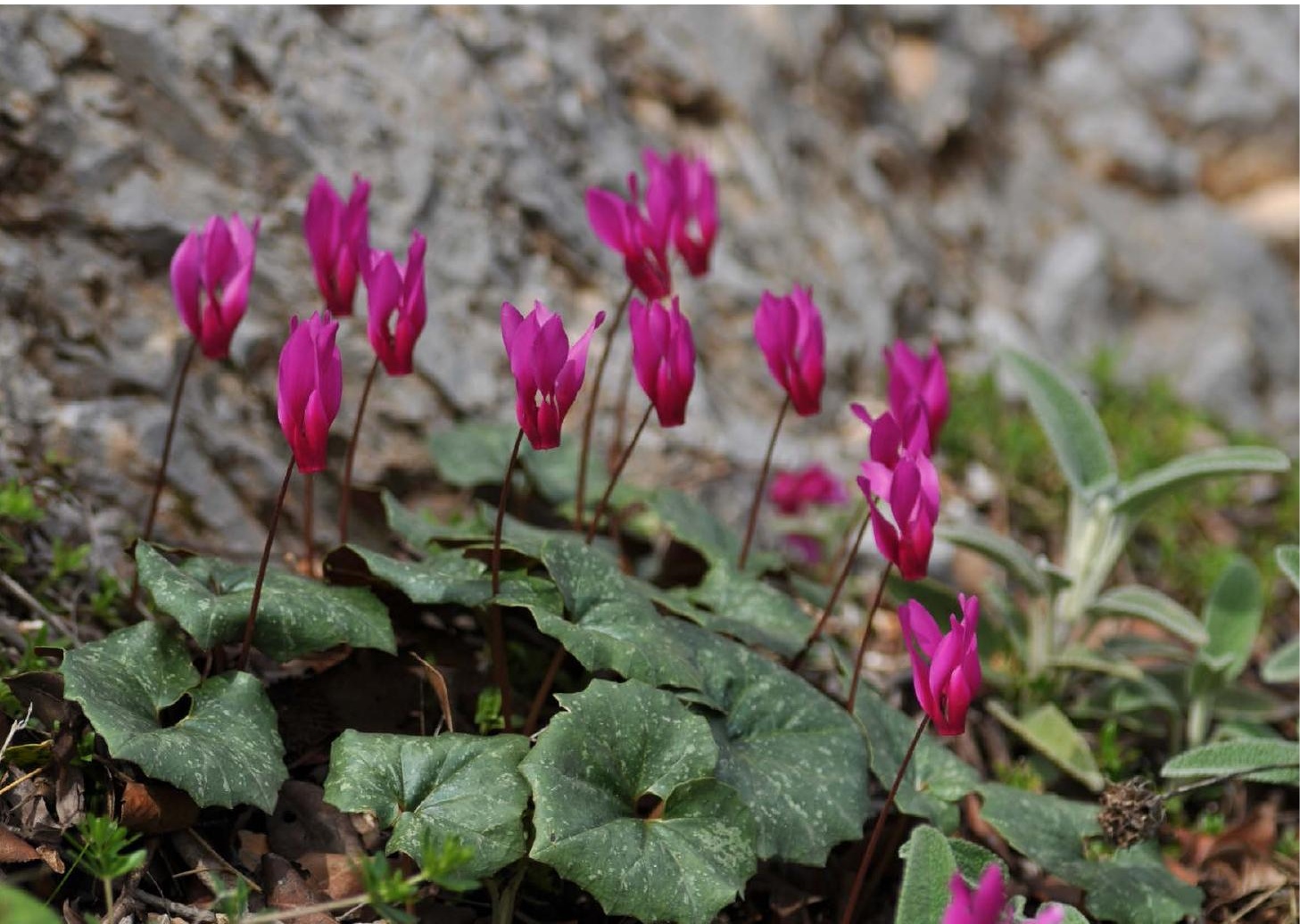




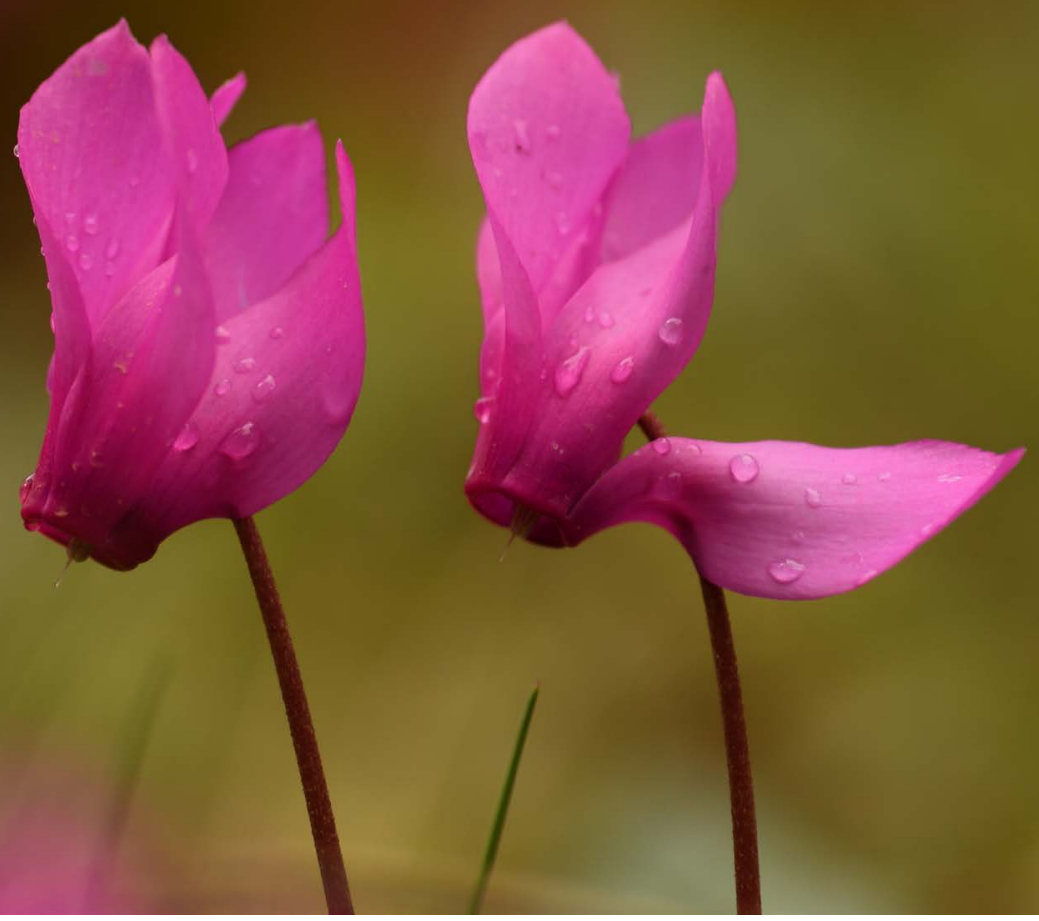

\section{THREATS}

Trade, collection and habitat destruction.

\section{PROTECTION}

CITES Washington Convention-Annex II.

EU Wildlife Trade Regulation-Annex B.

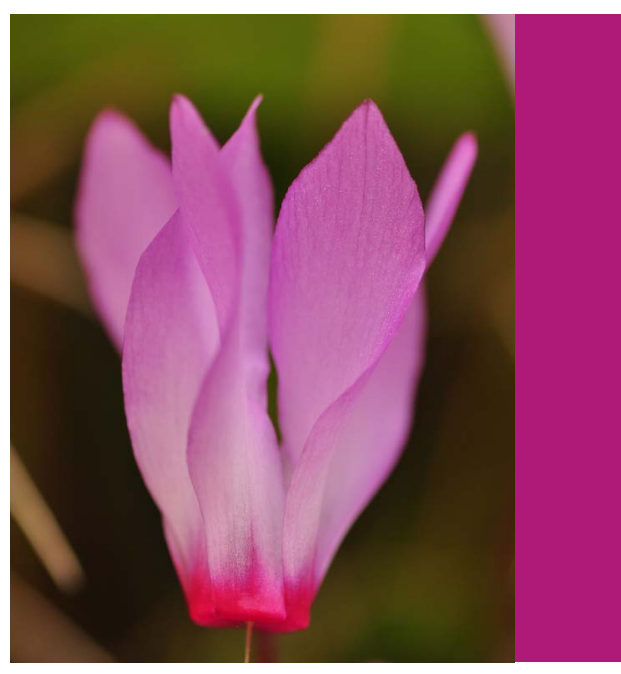




\section{Winter daffodil}

Sternbergia lutea (L.) Ker-Gawl. Ex Spreng

\section{DESCRIPTION}

Blooms and leaves in autumn, from September to November. Leaves bright green, up to $12 \mathrm{~mm}$ wide; stay over the winter. Distinctly yellow flowers appear soon after leaves. Flower consists of six tepals about $3-3.5 \mathrm{~cm}$ long, six yellow stamens and a stigma.

\section{HABITAT}

In the Mediterranean and sub-Mediterranean on rocky and grassy areas, pastures, among stone boulders. In the Pannonian basin, on dry drained areas with meadow vegetation.

\section{DISTRIBUTION}

From Algeria and Spain in the west, across the Balkan Peninsula to Turkmenistan and southern Russia in the east, and Israel in the south.

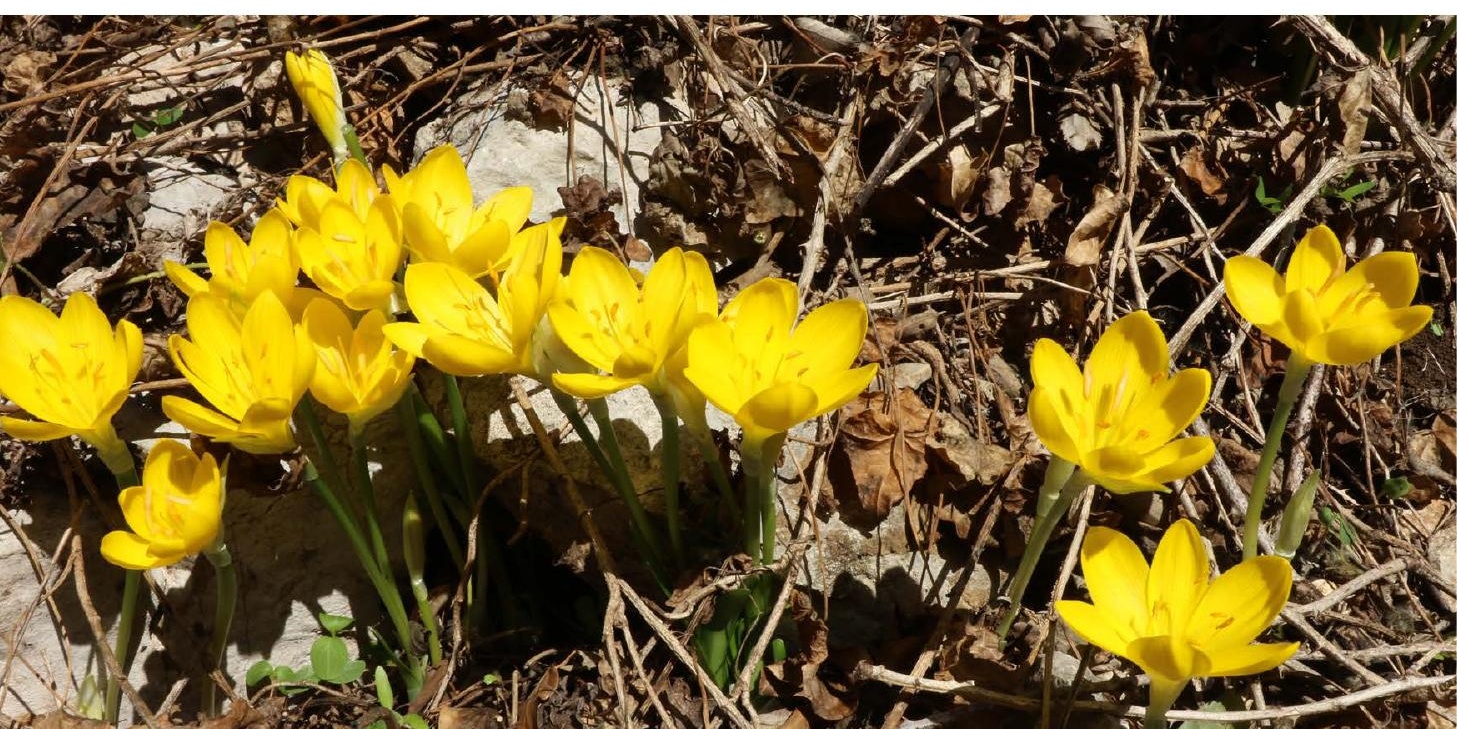




\section{Common snowdrop}

Galanthus nivalis L.

\section{DESCRIPTION}

A low perennial plant with a spherical bulb, which produces usually two very narrow leaves and a solitary, pendulous, bell-shaped white flower, held on a slender pedicel.

\section{HABITAT}

Woodland, grassland and shrubland. Likes to grow in well-drained, chalk and limestone soils, under the shade of deciduous trees.

\section{DISTRIBUTION}

Central and southern Europe, the Caucasus, Asia Minor.

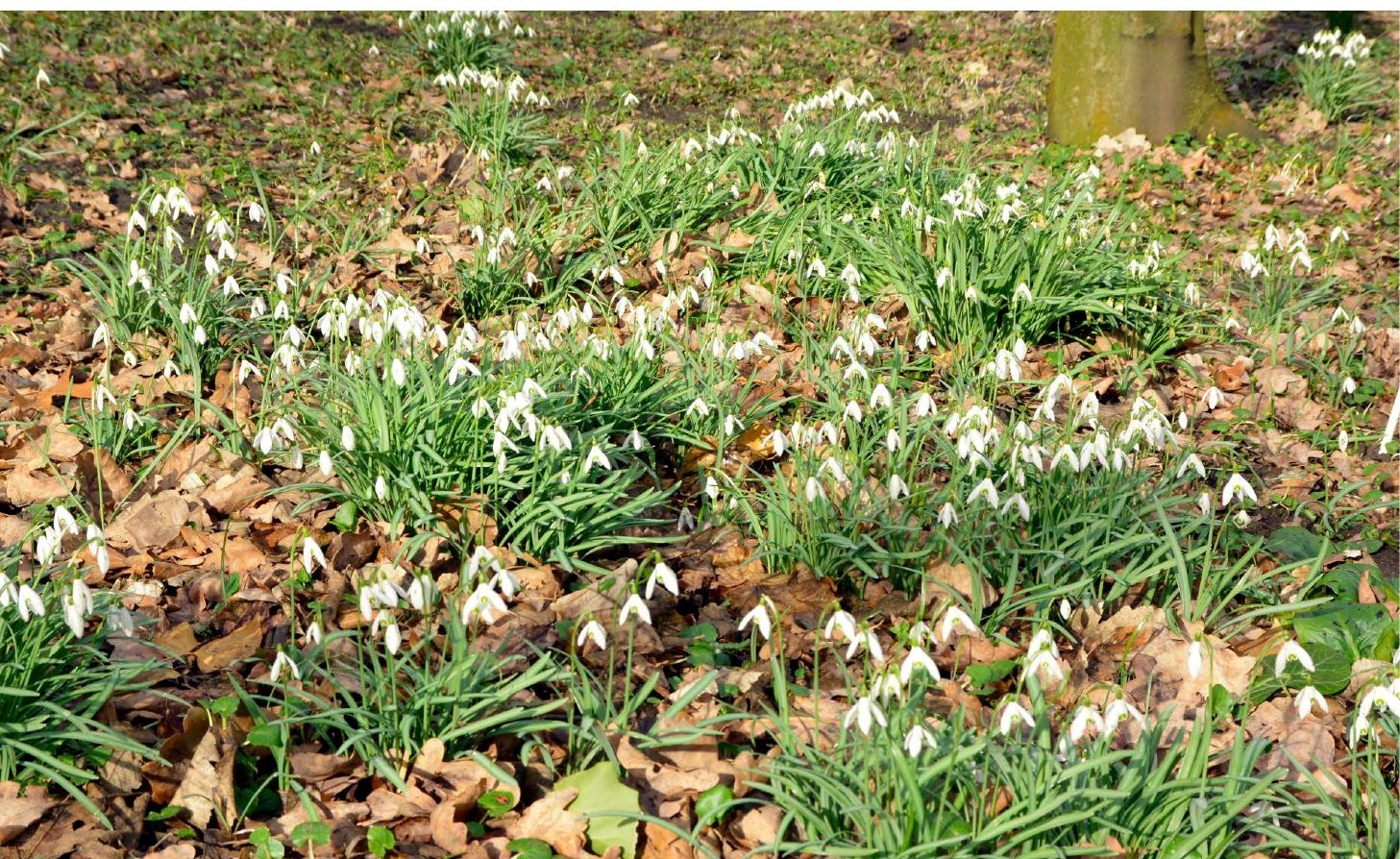




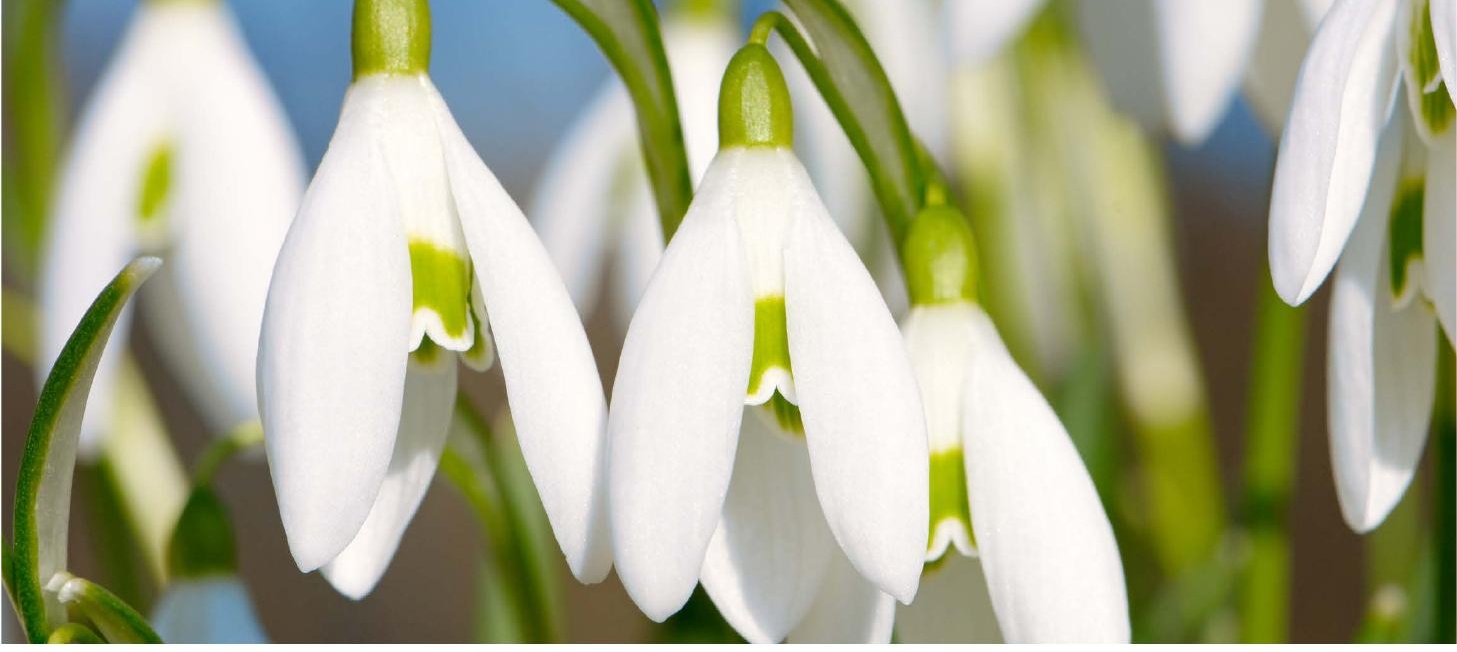

\section{THREATS}

One of the most often destroyed spring plants, picked and excavated for ornamental purposes. Another threat is the loss of habitats as a result of shrinking forests and forest management.

\section{PROTECTION}

CITES Washington Convention-Annex II.

Cut flowers obtained from cultivated specimens are not subject to the provisions of the Convention.

EU Wildlife Trade Regulation-Annex B.

IUCN World Red Threatened Species ListNear Threatened (Europe and Global).

Habitats Directive-Annex V.
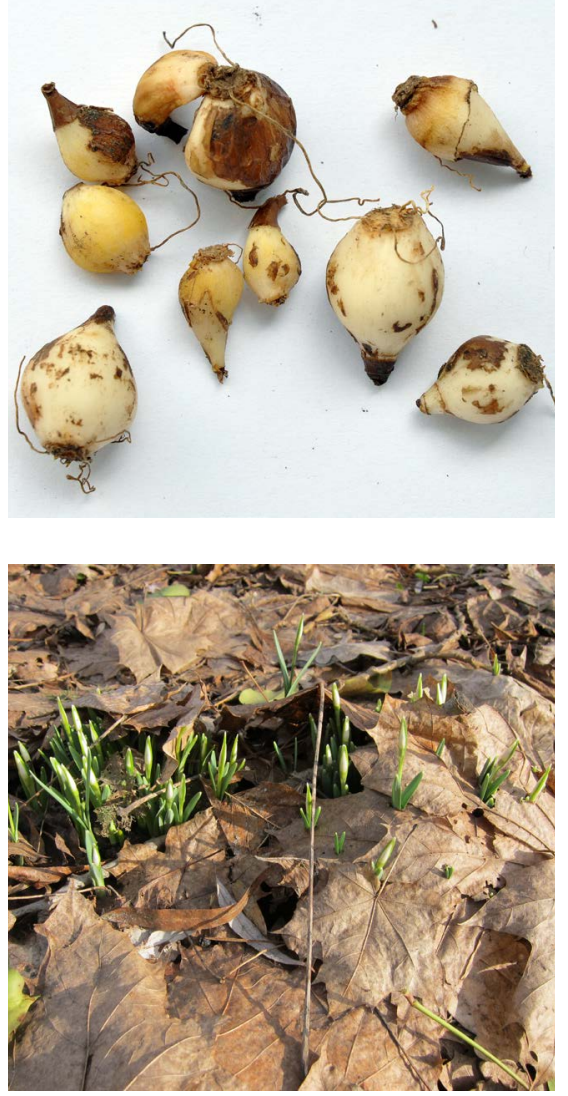


\section{Holy orchid}

Anacamptis sancta (L.) R.M. Bateman \& al.

\section{DESCRIPTION}

Orchid with a cylindrical inflorescence, formed by uniformly coloured, unspotted flowers.

\section{HABITAT}

Phrygana, short grassland, scrub and open woodland, on dry, calcareous substrates.

\section{DISTRIBUTION}

East Mediterranean: Greece, Cyprus, Turkey, southwards to Jordan and Syria, through Lebanon and Israel. 



\section{Spurred helleborine}

Cephalanthera epipactoides Fisch. \& C.A. Mey.

\section{DESCRIPTION}

Robust orchid with 2-4 leaves and up to 30 , white, spurred flowers which are not fully opened.

\section{HABITAT}

Coniferous and deciduous woodland with oaks or scrub, on alkaline substrates.

\section{DISTRIBUTION}

An East Mediterranean element, apparently restricted to eastern Greece, including the East Aegean Islands, and western Turkey. 


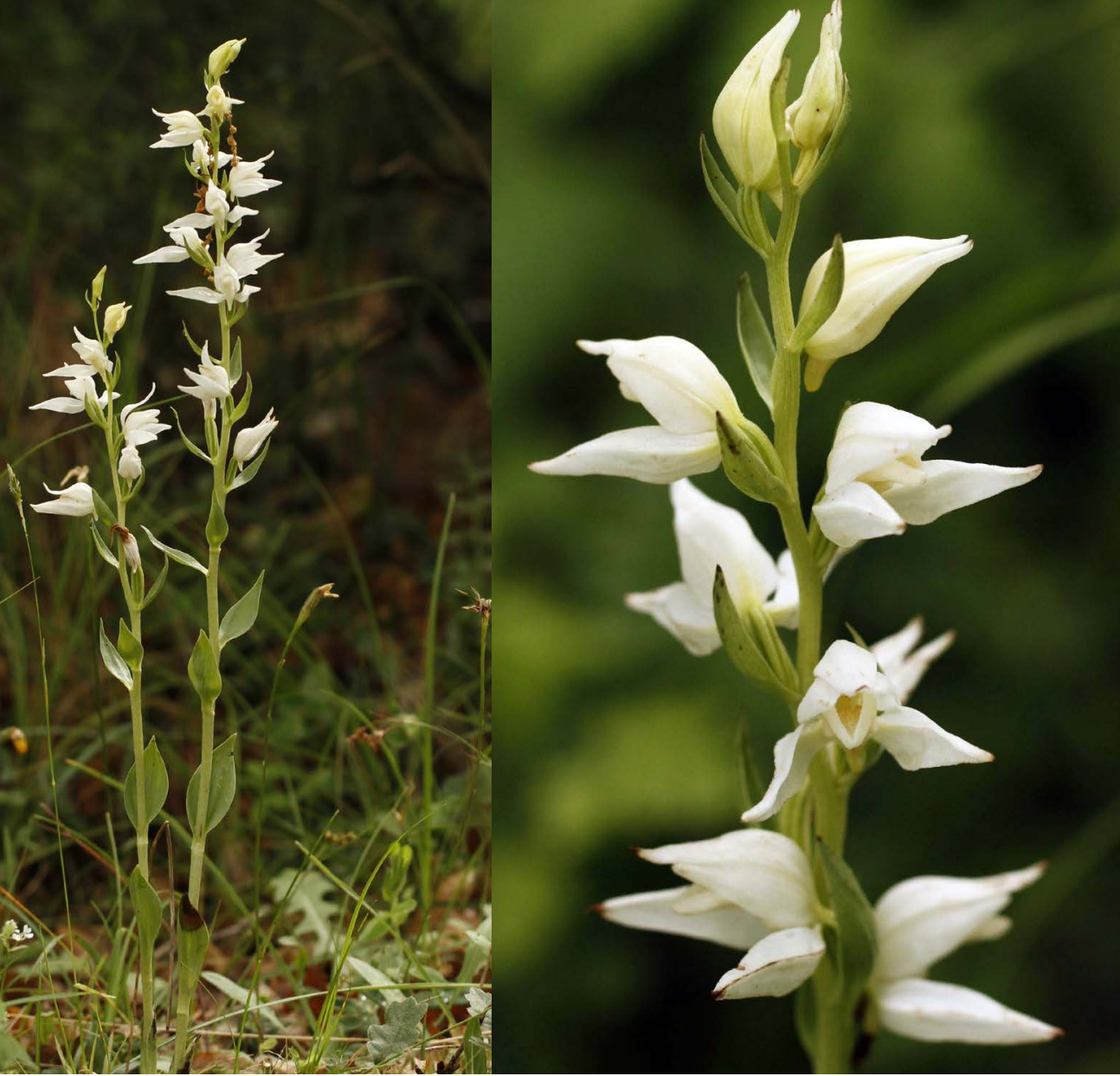

\section{THREATS}

Natural system modifications (fire and fire suppression), grazing, tourism, deforestation for building purposes, insecticides (reduction of pollinators), collection, transportation and service corridors (roads and railroads).

\section{PROTECTION}

CITES Washington Convention-Annex II.

EU Wildlife Trade Regulation-Annex B.

IUCN Red List of Threatened Species-Vulnerable (Europe), Data Deficient (Global). 


\section{Lady's-slipper orchid}

Cypripedium calceolus L.

\section{DESCRIPTION}

A long-lived perennial orchid with shoots growing up to $60 \mathrm{~cm}$ and flowers wide up to 9 $\mathrm{cm}$. Each shoot has up to four ovate leaves with parallel venation. Flowers composed of three red-brown, twisted petals and one slipper-shaped yellow labellum. Lady's-slipper orchid blooms from May to early June. Spreads using seeds or horizontal stems.

\section{HABITAT}

It grows in light forests and thickets on calcareous soils.

\section{DISTRIBUTION}

It occurs from central Europe to eastern Asia.

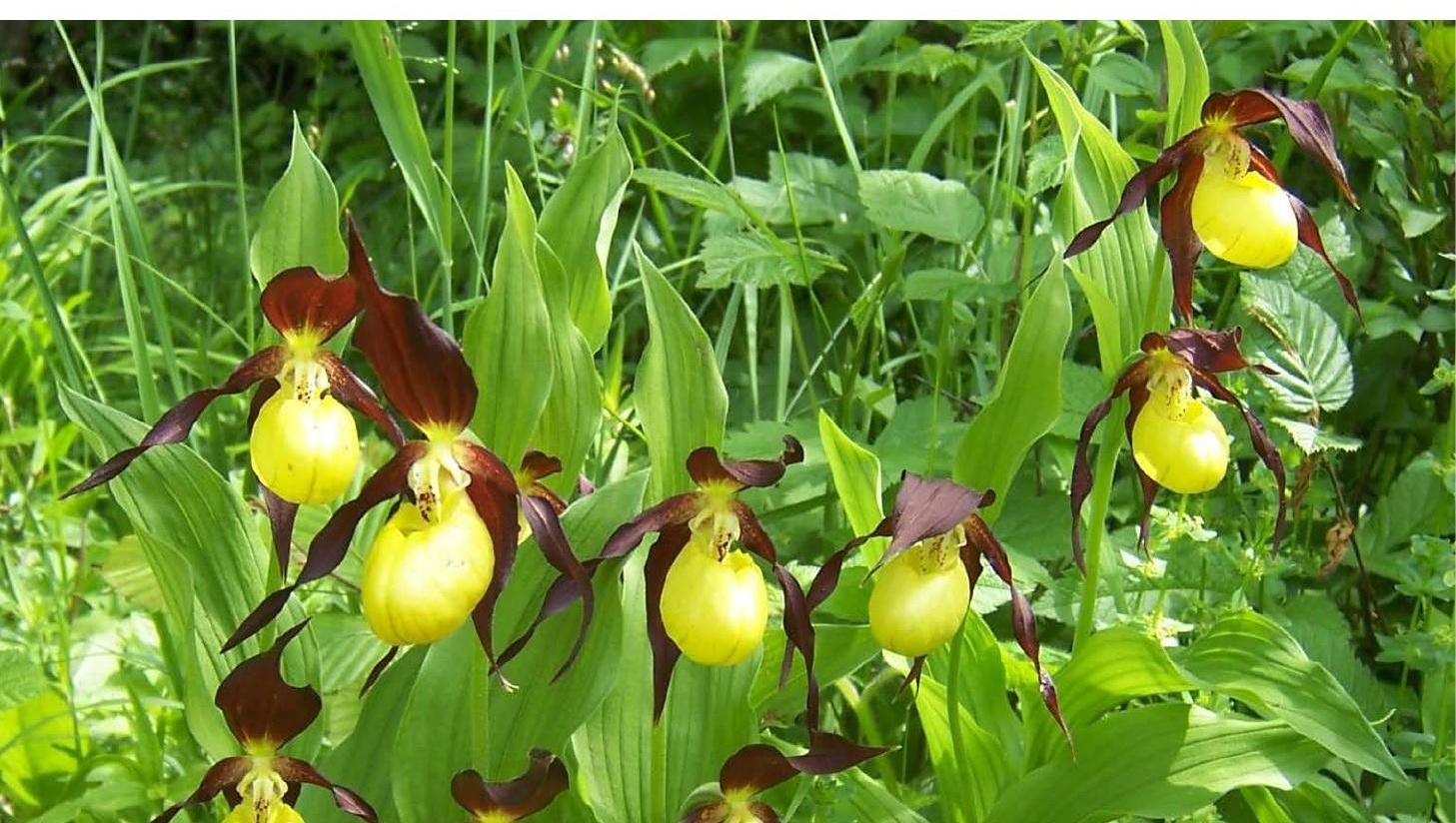




\section{Heath Spotted-orchid}

Dactylorhiza maculata (L.) Soó

\section{DESCRIPTION}

Perennial plant up to $70 \mathrm{~cm}$ tall with 4-10 leaves, usually with spots. Flowers from light to dark pink, gathered in a dense spike.

The genus Dactylorhiza has numerous taxa which are often taxonomically problematic, and therefore worthy of critical consideration.

\section{HABITAT}

Damp places in marshes, fens, bogs, and damp meadows; sunny places; also undergrowth of forests, at the edges of streams and in areas with bushes.

\section{DISTRIBUTION}

Almost all of Europe with the exception of the most southern parts and Siberia.

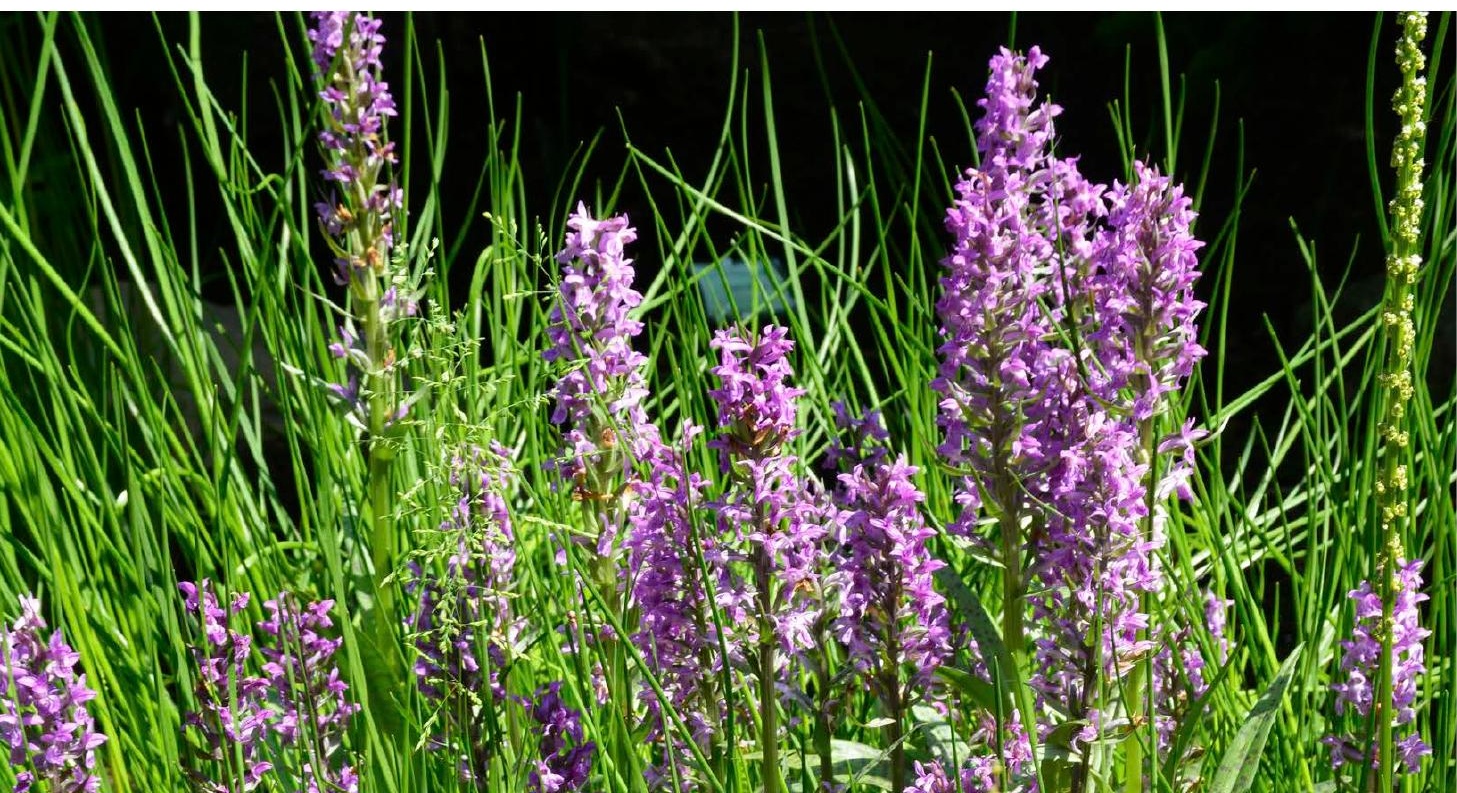




\section{Violet helleborine}

Epipactis purpurata Sm.

\section{DESCRIPTION}

Mid-high perennial with straight stem, rhizome, lanceolate leaves, inflorescence with many wide-open flowers on short, bent stalks. Many parts of plants with violet tint.

The genus Epipactis has numerous taxa which are often taxonomically problematic, and therefore worthy of critical consideration.

\section{HABITAT}

Deciduous forest-hornbeam-oak or beechwood, forest roads margins, often on soils rich in calcium carbonate.

\section{DISTRIBUTION}

From eastern Spain and England to north-eastern Poland. Separate subspecies are endemic on the south Balkan peninsula and south Caucasus.
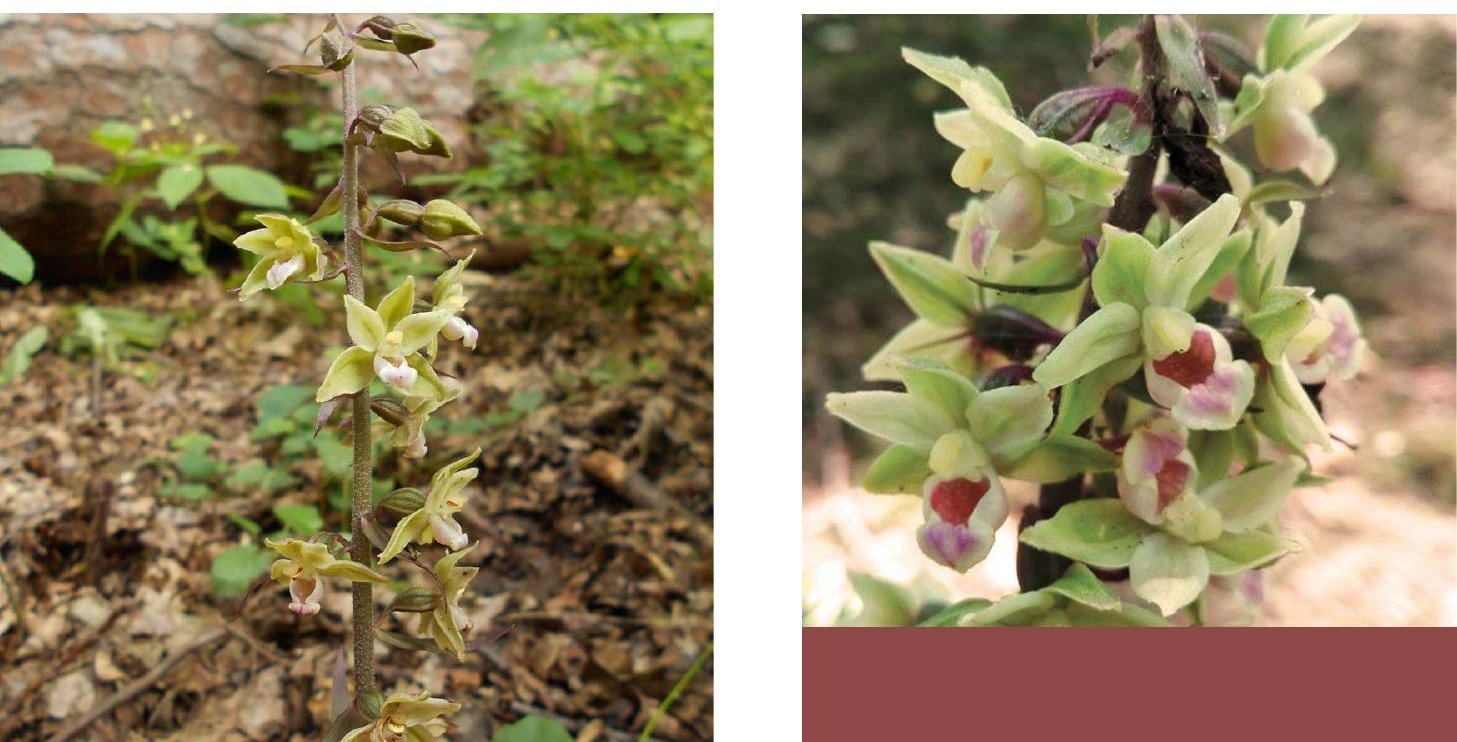



\section{Frivald's frog orchid}

Gymnadenia frivaldii Griseb.

\section{DESCRIPTION}

Slender plant, up to $30 \mathrm{~cm}$ high, with a dense inflorescence of numerous, small, pinkishwhite flowers.

\section{HABITAT}

Wet meadows and bogs, on siliceous substrates.

\section{DISTRIBUTION}

Endemic to the Balkan Peninsula, from southern Carpathians to northern Greece. 


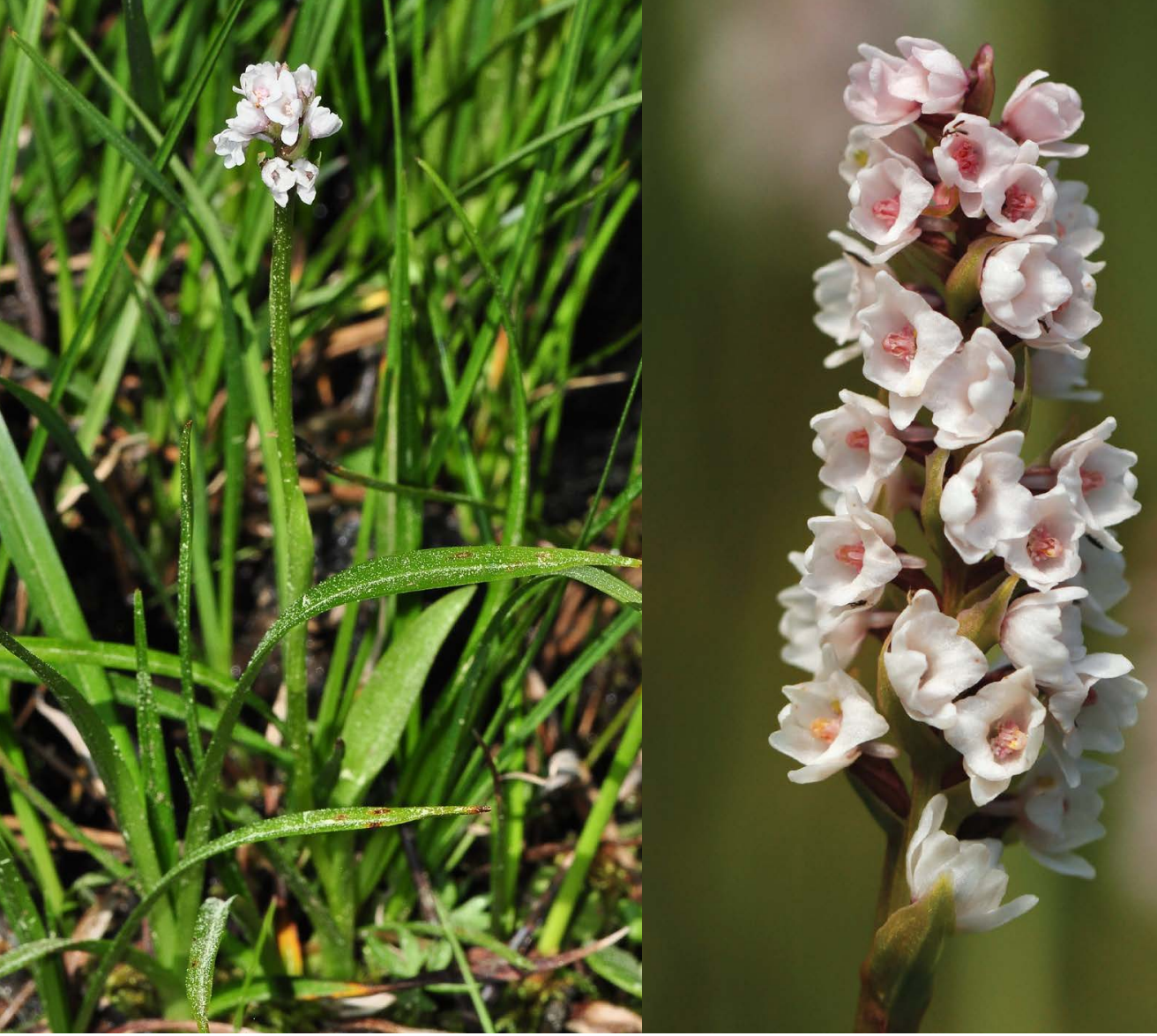

\section{THREATS}

Residential and commercial development (tourism and recreation areas), agriculture (livestock farming and ranching), human intrusions and disturbance (recreational activities), natural ecosystem modifications.

\section{PROTECTION}

CITES Washington Convention-Annex II.

EU Wildlife Trade Regulation-Annex B.

IUCN Red List of Threatened Species-Least Concern. 


\section{Lizard orchid}

Himantoglossum adriaticum H.Baumann

\section{DESCRIPTION}

Tall orchid recognised by an extremely long pink curved labellum and a greenishpinkish-white hood marked with purple veins. Elongate and lax inflorescence, typically composed of 15-40 flowers.

\section{HABITAT}

Calcareous soils in natural and semi-natural, dry and mesophilic grasslands or open woodlands.

\section{DISTRIBUTION}

Adriatic region of the Mediterranean, extending to Hungary, Czech Republic and Slovakia in the northeast.

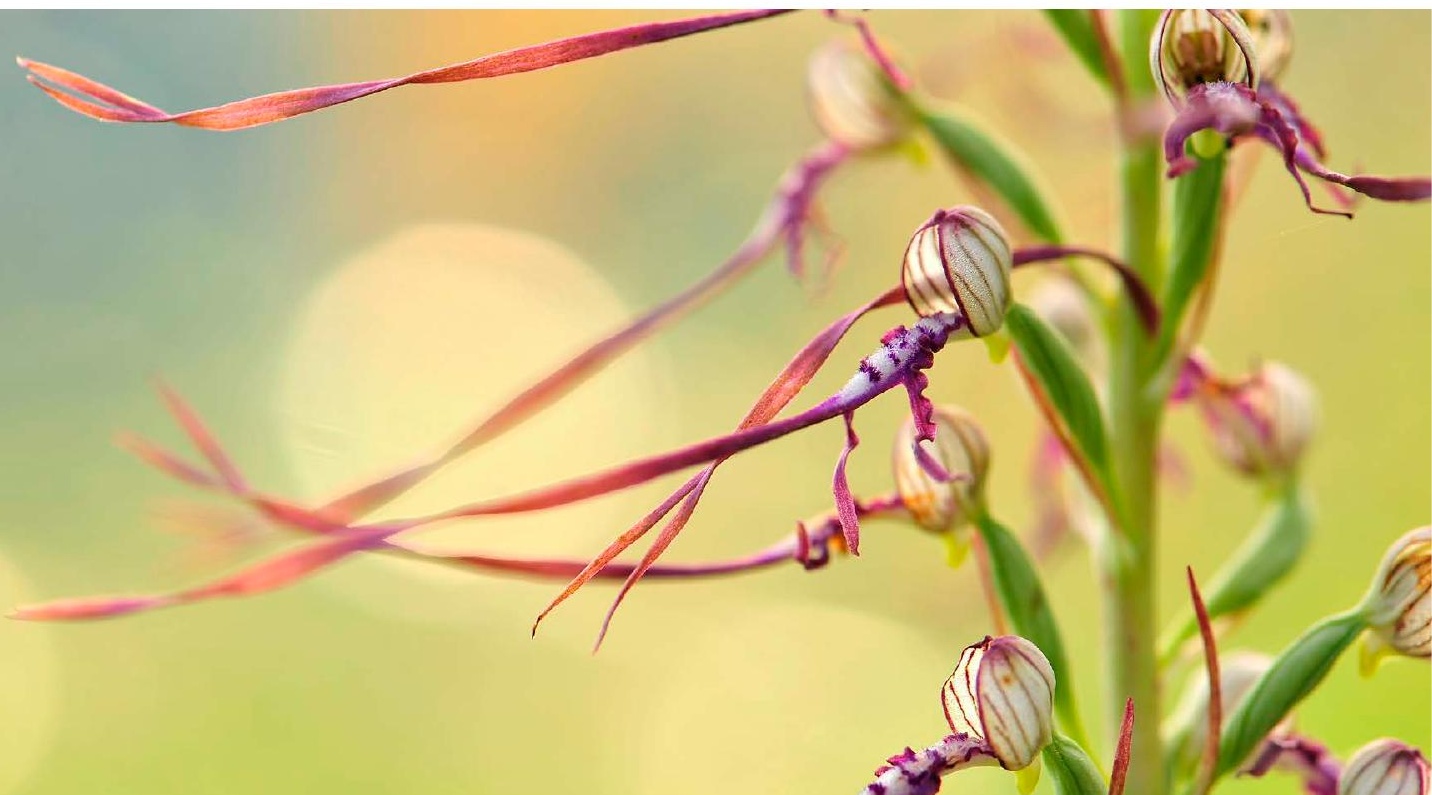




\section{Komper's orchid}

Himantoglossum comperianum (Steven) P. Delforge

\section{DESCRIPTION}

Robust and spectacular orchid with large flowers, brownish-purple hood and a paler, rose-pink lip that extends to four narrow and very long segments.

\section{HABITAT}

Open coniferous and deciduous woodland, on calcareous substrates.

\section{DISTRIBUTION}

From Crimea southwards to Lebanon, Syria, Iraq and Iran, through Anatolia and the East Aegean Islands. Local and very rare. 


\section{Bird's-nest orchid}

Neottia nidus-avis (L.) Rich.

\section{DESCRIPTION}

A non-photosynthetic orchid that derives all its nutrition from a mycorrhizal fungus in the soil and litter. Name derives from a comparison of the tangled roots to a bird's nest. Beige-brown, yellowish or even white shoot, up to $40 \mathrm{~cm}$. Flowers without spur, gathered in the spike, the same color as the shoot. Labellum divided into two lobes, the remaining petals form a 'helmet'. Flowering occurs from late May to June.

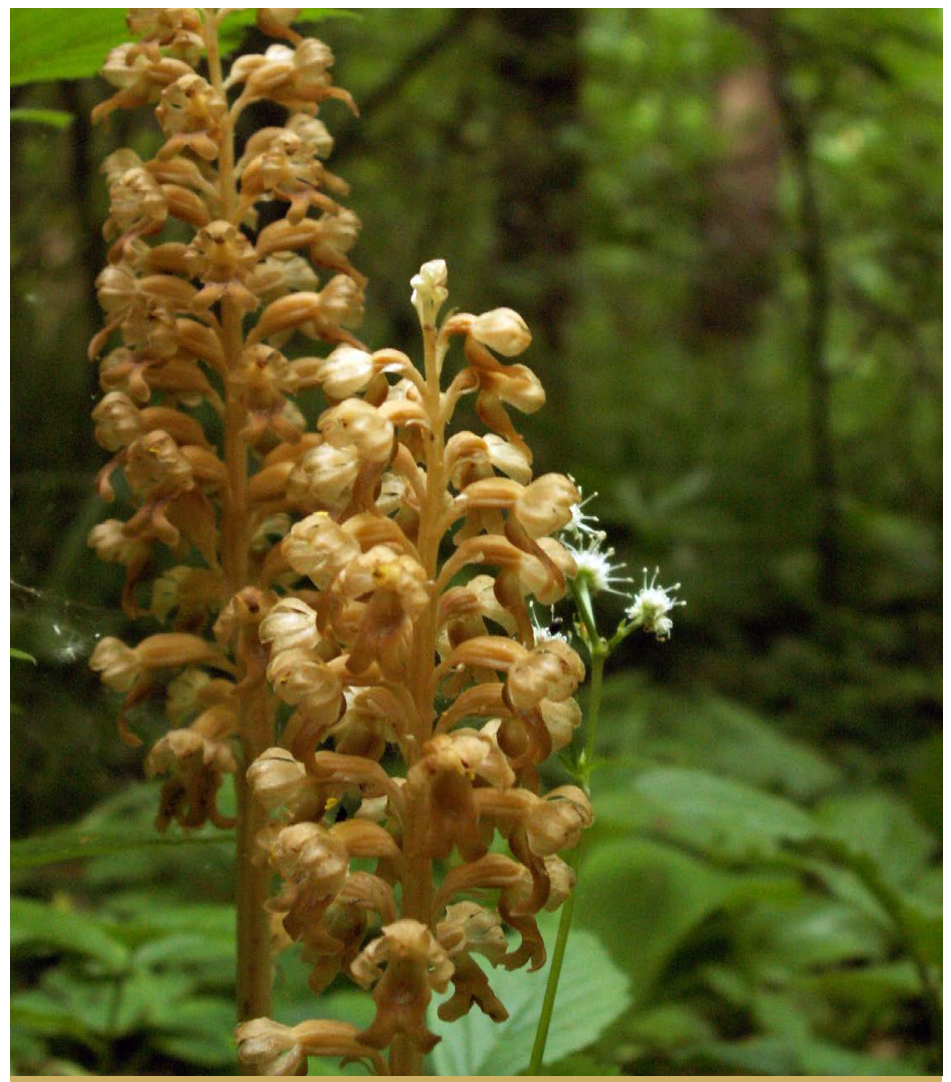




\section{HABITAT}

It grows in shady woodland, especially beech and hornbeam forests.

\section{DISTRIBUTION}

It occurs across most of Europe, up to the Caucasus and the Urals. Also, it can be found in northern Africa.

\section{DANGER}

Forest management and destruction of undergrowth are a threat to the species.

\section{PROTECTION}

CITES Washington ConventionAnnex II.

IUCN Red List of Threatened Species-Least Concern (Europe, Global).

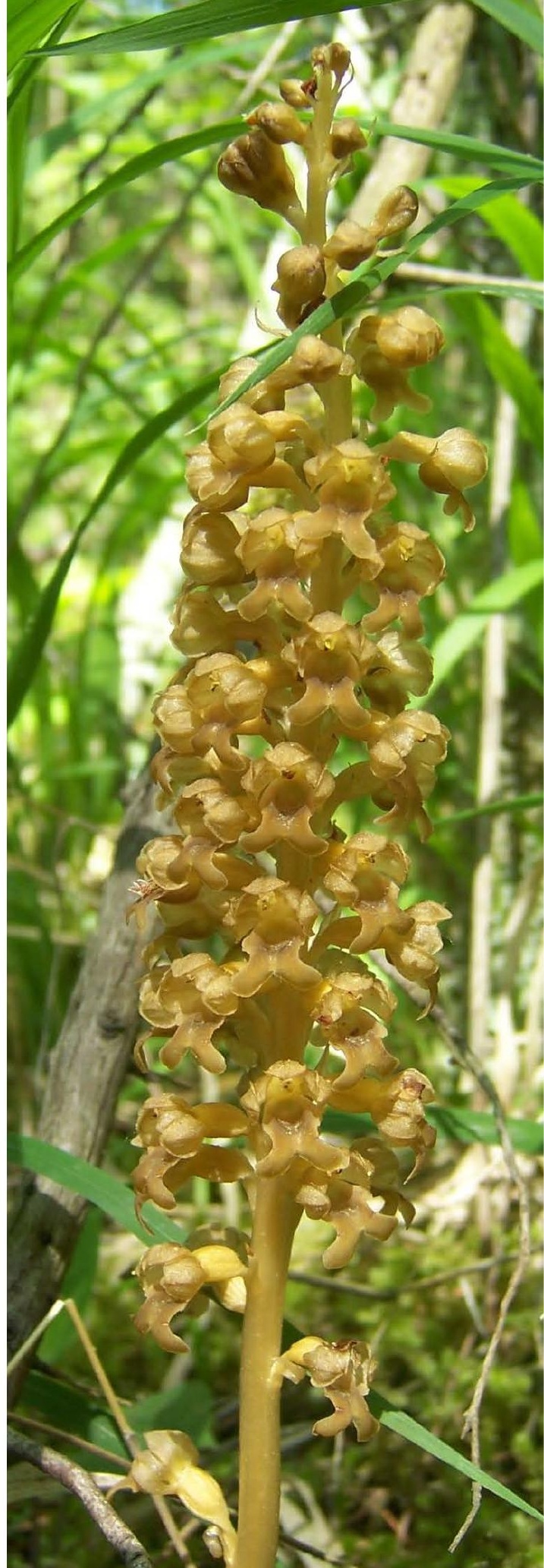




\section{Burnt orchid}

Neotinea ustulata (L.) R.M.Bateman \& al.

\section{DESCRIPTION}

Inflorescence of this small orchid composed of up to 15-50(70) flowers. Each has a three-lobed lip with crimson red spots, while the sepals and petals are red-brown. The specific epithet ustulata means "slightly burned", which refers to the dark appearance of the flower spike. 


\section{HABITAT}

Grasslands, fens, mountain meadows, valleys and wet grasslands throughout central and south Europe.

\section{DISTRIBUTION}

Central and southern Europe, reaching southern Sweden in the north and extending to the Caucasus and the Ural Mountains in the east.

\section{THREATS}

Populations of this orchid have suffered large declines due to habitat destruction and intense agriculture. It requires unfertilised and unploughed grasslands.

\section{PROTECTION}

CITES Washington Convention-Annex II.

EU Wildlife Trade Regulation-Annex B.

IUCN Red List of Threatened SpeciesLeast Concern. 


\section{Asclepius' spider orchid}

Ophrys aesculapii Renz

\section{DESCRIPTION}

Up to 14 flowers formed by yellowish-green sepals, and upper petals and a brown median lip usually bearing an $\mathrm{H}$-shaped pattern and a yellow margin.

\section{HABITAT}

Open woodland, scrub or phrygana.

\section{DISTRIBUTION}

Endemic to Greece. 


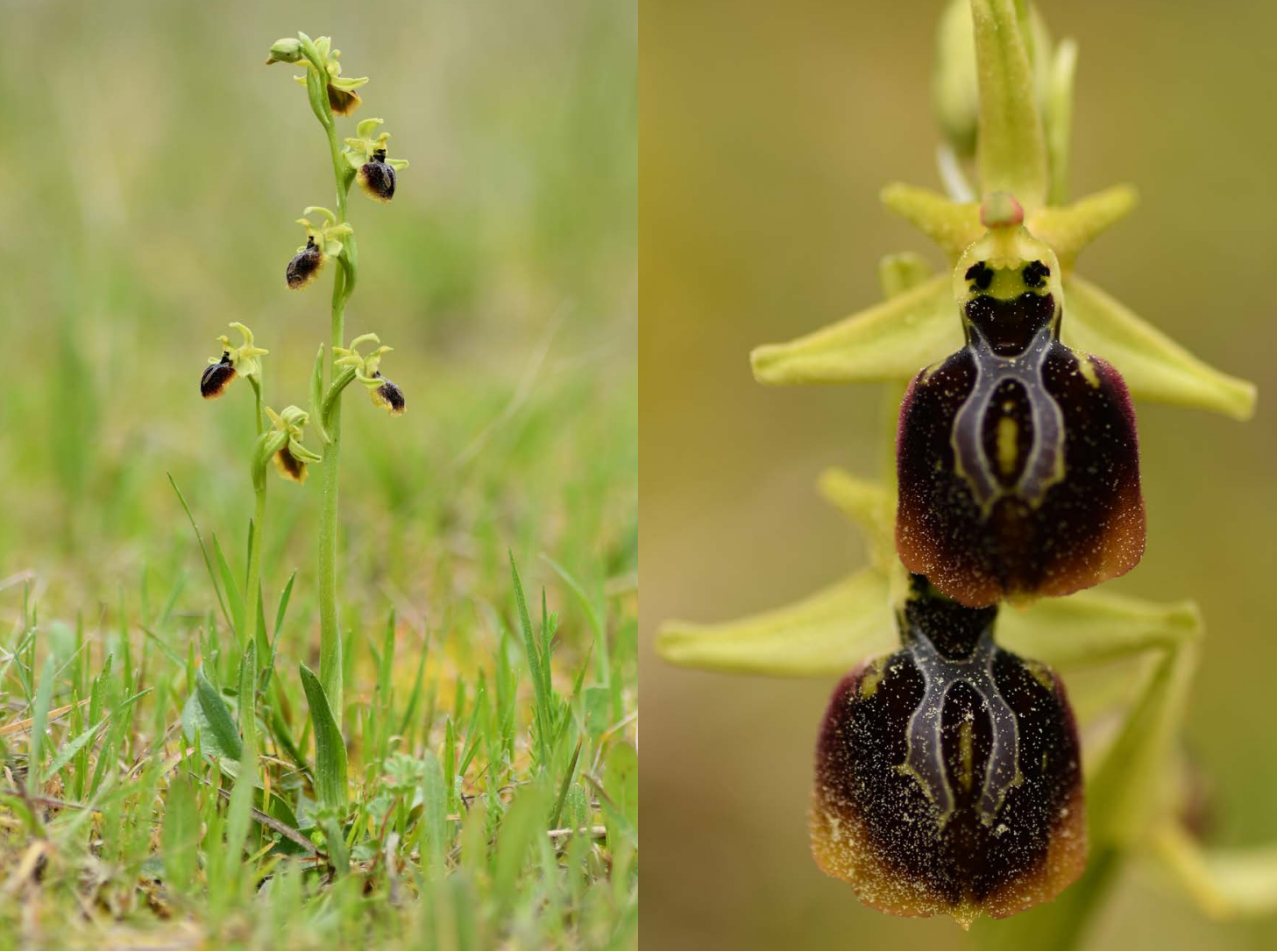

\section{THREATS}

Residential and commercial development (housing and urban areas; tourism and recreation areas), biological resource use (plant gathering).

\section{PROTECTION}

CITES Washington Convention-Annex II.

EU Wildlife Trade Regulation-Annex B. 


\section{Reinhold's bee-orchid}

Ophrys reinholdii H. Fleischm.

\section{DESCRIPTION}

Plant with 2-8 flowers. Sepals and upper petals pink, flushed with green. Median lip blackish-purple with hairy lateral lobes and usually white pattern in the center.

\section{HABITAT}

Woodland, phrygana, grassland and olive groves.

\section{DISTRIBUTION}

From Albania to Iran, through Greece, Turkey, Cyprus and Iraq.

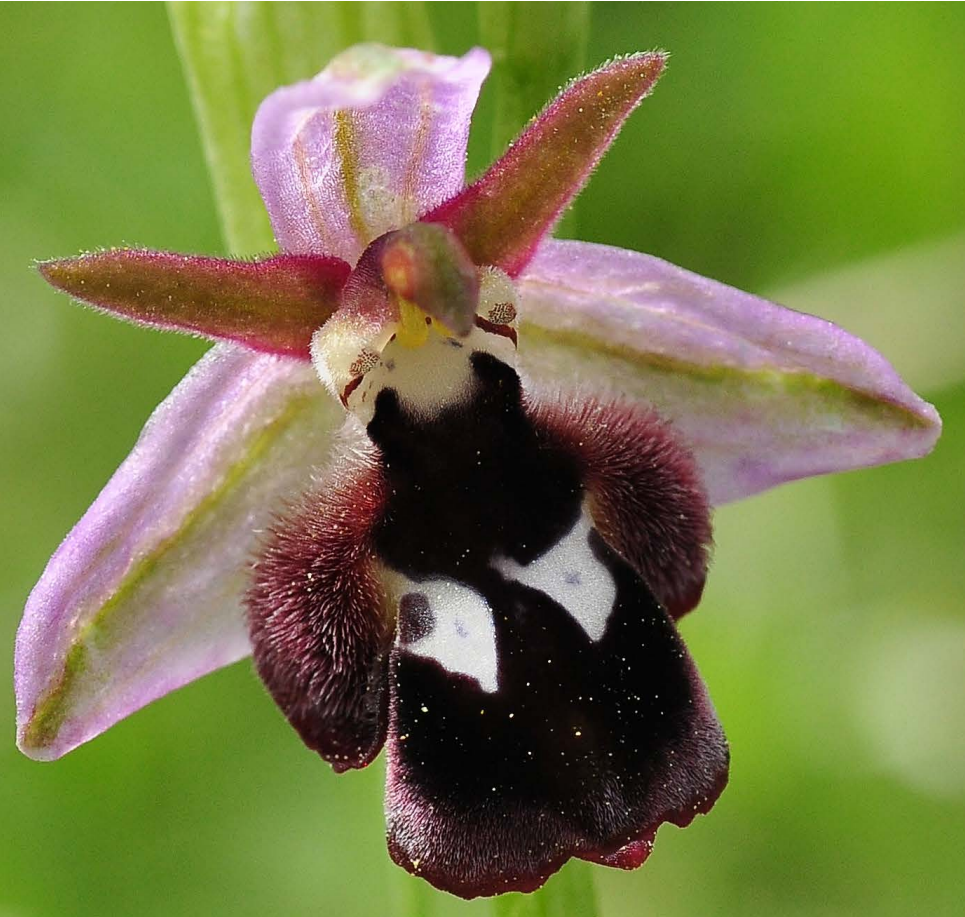




\section{Anatolian orchid}

Orchis anatolica Boiss.

\section{DESCRIPTION}

Orchid with a lax inflorescence and spotted leaves. Flowers pink, except for the whitish, purple-spotted center.

\section{HABITAT}

Open places in maquis, scrub, phrygana or coniferous woodland.

\section{DISTRIBUTION}

East Mediterranean region, extending from Greece to Iran.

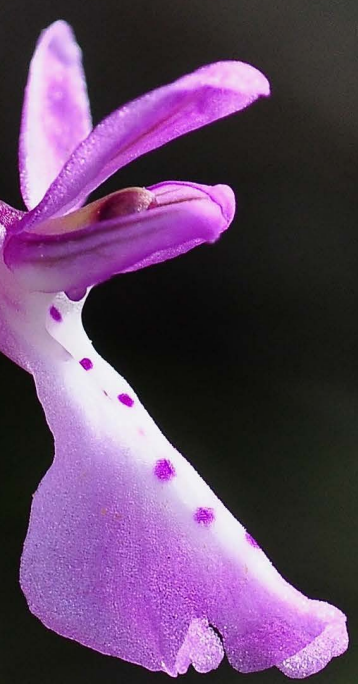




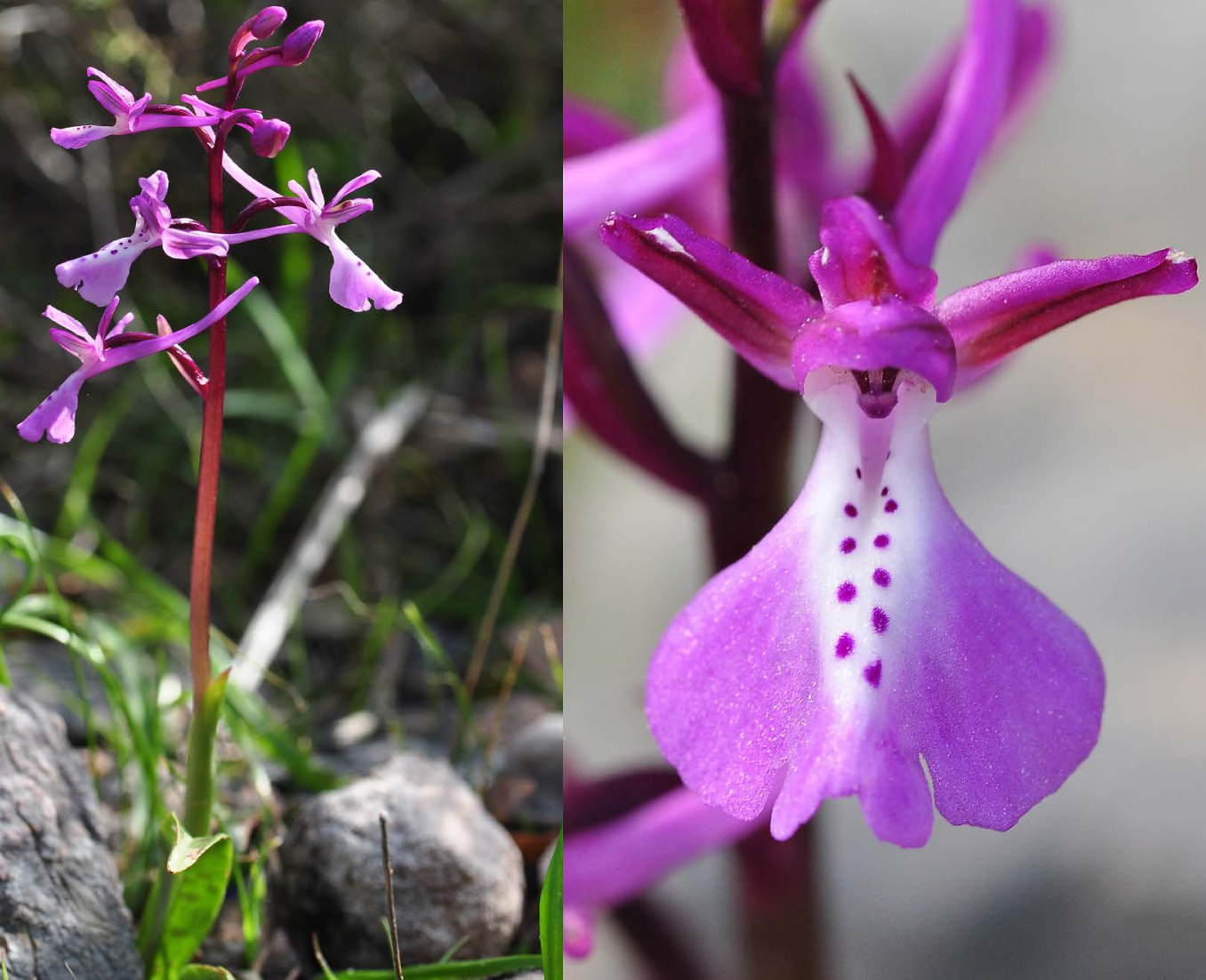

\section{THREATS}

Residential and commercial development (housing and urban areas; tourism and recreation areas), agriculture (annual and perennial non-timber crops), biological resource use (plant gathering; logging and wood harvesting).

\section{PROTECTION}

CITES Washington Convention-Annex II.

EU regulation of trade of fauna and flora-Annex $B$.

IUCN Red List of Threatened Species-Least Concern. 


\section{Greater butterfly-orchid}

Platanthera chlorantha (Custer) Rchb.

\section{DESCRIPTION}

Greater butterfly-orchid is a herbaceous perennial growing up to $50 \mathrm{~cm}$. The shoot with two large, elliptical, shiny leaves at the base and smaller, lanceolate leaves on the upper part. The flowers greenish-white, with spreading sepal and petals, narrow and undivided labellum and long spur form a loose spike. Anthers widely spaced, close to each other at the top. Blooms from May to July.

\section{HABITAT}

The greater butterfly-orchid grows in forests, scrubs and grassland on calcareous soils.

\section{DISTRIBUTION}

It occurs in Europe, northern Africa and Turkey. 


\section{Long-lipped tongue-orchid}

Serapias vomeracea (Burm.f.) Briq.

\section{DESCRIPTION}

Species usually $20-40 \mathrm{~cm}$ high, inflorescence bears 3-10 reddish flowers and conspicuous lanceolate bracts. Species highly variable in colour and shape.

\section{HABITAT}

Dry and wet meadows, pastures, thickets, clearings and scrubland, frequently on clayey substrate, from full light to partial shade.

\section{DISTRIBUTION}

Mediterranean-Atlantic distribution.

\section{THREATS}

The populations are decreasing in parts of its range due to habitat loss but can also increase due to new habitat colonisation.

\section{PROTECTION}

CITES Washington Convention-Annex II.

EU regulation of trade of fauna and flora-Annex B.

IUCN Red List of Threatened SpeciesLeast Concern (Europe). 



\section{Autumn lady's-tresses}

Spiranthes spiralis (L.) Chevall.

\section{DESCRIPTION}

Slender orchid with small, white to yellowish-green flowers, arranged in a helicoid inflorescence.

\section{HABITAT}

Sunny places in open coniferous woodland, maquis and olive groves.

\section{DISTRIBUTION}

Europe, eastwards to Iran and southwards to North Africa.

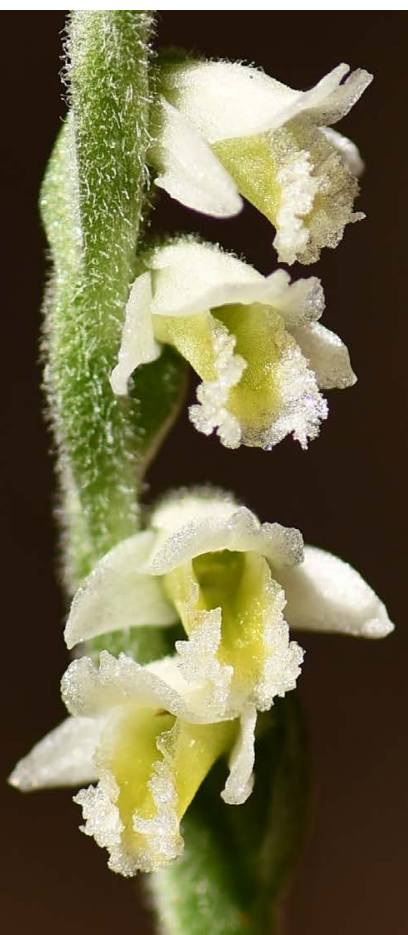



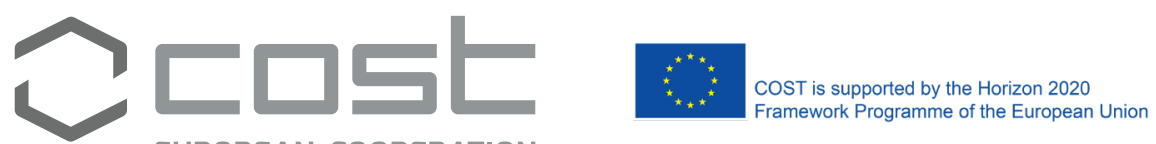

EUROPEAN COOPERATION IN SCIENCE \& TECHNOLOGY

This publication is based upon work from COST Action CA18201 - An integrated approach to conservation of threatened plants for the 21st Century, supported by COST (European Cooperation in Science and Technology).

COST (European Cooperation in Science and Technology) is a funding agency for research and innovation networks. Our Actions help connect research initiatives across Europe and enable scientists to grow their ideas by sharing them with their peers. This boosts their research, career and innovation. 



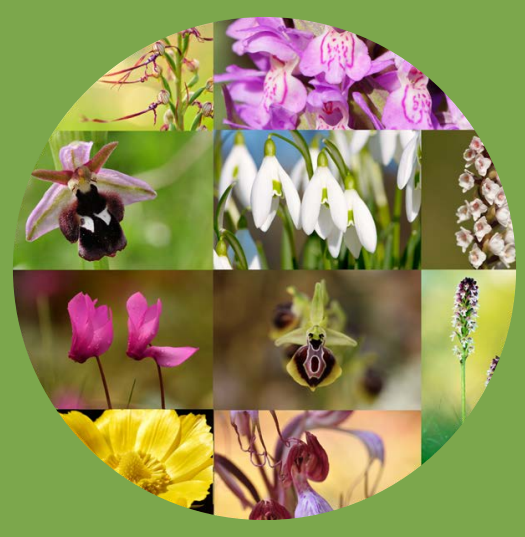

